\title{
Controlling wound odor with metronidazole: a systematic review
}

\author{
Controle do odor de feridas com metronidazol: revisão sistemática \\ Control del olor de heridas con metronidazol: revisión sistemática
}

\section{Diana Lima Villela de Castro ${ }^{1,2}$, Vera Lúcia Conceição de Gouveia Santos ${ }^{3}$}

${ }^{1}$ Universidade de São Paulo, Escola de Enfermagem, São Paulo, SP, Brasil.

${ }^{2}$ AC Camargo Cancer Center, Gerência de Enfermagem, São Paulo, SP, Brazil.

${ }^{3}$ Universidade de São Paulo, Escola de Enfermagem, Departamento de Enfermagem Médico-Cirúrgica, São Paulo, SP, Brazil.

\begin{abstract}
Objective: Verifying the evidence of therapeutic efficacy in the topical application of metronidazole for controlling wound odor. Methods: A systematic literature review, according to the Cochrane Collaboration recommendations. Results: 329 articles were identified in the Cochrane, LILACS, SciELO, CINAHL and PubMed databases, with 14 of them being included in the final sample. Two of the studies were double-blind randomized clinical trial studies. Conclusion: The actual effectiveness of metronidazole in controlling wound odor cannot yet be evidenced due to the absence of strong evidence from studies on the subject, despite clinical practice recommending its benefits.
\end{abstract}

\section{DESCRIPTORS}

Wounds and Injuries; Deodorization; Metronidazole; Wound Infection; Review. 


\section{INTRODUCTION}

Colonization and bacterial infection are factors that interfere with wound healing, especially in chronic wounds. To control these factors, antiseptics and topical antibiotics are accepted as the best option for local infection treatment (in some cases the use of systemic antibiotics is necessary). Infection in wounds slows the healing process and may have systemic complications if not quickly controlled ${ }^{(1)}$.

Unpleasant odor is a common and distressing concern for people with infected wounds, as well as for their family members and caregivers. Patients with fetid wounds often experience social isolation, depression, shame, embarrassment and lack of appetite, factors that can have a negative impact on their quality of life. Nurses who treat these patients face difficult clinical challenges when treating the cause and controlling the symptoms ${ }^{(2)}$.

Wound odor is not only experienced by patients under palliative care, it is also perceived in chronic leg wounds and pressure ulcers. Wound necrosis contributes to the occurrence of odor, but it cannot be perceived as the main cause of its emergence ${ }^{(3)}$.

There are several silver-based, iodine-based, honeybased and topical antibiotic products available to help odor control. Among topical antibiotics, metronidazole has been described as effective in controlling wound odor. Metronidazole is a nitroimidazole derivative with antiprotozoal action. It also has bactericidal activity against gram-negative anaerobic bacilli, all sporulated anaerobic cocci and grampositive bacilli. Putrid odor is characteristic of local infection by anaerobic bacteria, which justifies its action and use for odor control( ${ }^{(2)}$.

Thus, we aimed to verify the evidence of therapeutic efficacy in using topical metronidazole for controlling wound odor.

\section{METHOD}

We performed a systematic literature review (SR) on the use of metronidazole as topical wound therapy for odor control of any etiology according to the recommendations of the Cochrane Collaboration ${ }^{(4)}$. For this purpose, we included studies published in the Cochrane, LILACS, CINAHAL, SciELO and PubMed databases, until December 2014. Descriptors indexed on MeSH and DeCS databases were used according to PICO - Patient, Intervention, Comparison, and Outcome ${ }^{(4)}$ electronic search methodology:

\begin{tabular}{|c|l|}
\hline \multirow{1}{*}{$\mathbf{P}$} & "Deiscência da Ferida Operatória - Surgical Wound \\
Dehiscence" OR "Ferimentos e Lesões - Wounds and \\
Lesions" OR "Ferimentos Penetrantes - Penetrating \\
Wounds" OR "Infecção da Ferida Operatória - Surgical \\
Wound Infection" OR "Cicatrização - Healing" \\
OR "Úlcera Cutânea - Skin Ulcer" OR "Úlcera por \\
Pressão - Pressure Ulcer" OR "Pé Diabético - Diabetic \\
foot (infection)" OR "Úlcera do Pé - Foot Ulcer" OR \\
"Úlcera Varicosa - Varicose Ulcer" OR "Úlcera da Perna \\
- Leg Ulcer" OR "Infecção dos Ferimentos - Wound \\
infections" OR "Infecções Bacterianas e Micoses - \\
Bacterial infections and Mycoses" OR "Infecções por \\
Bactérias Gram-Negativas - Gram-Negative Bacterial \\
Infections" OR "Infecções por Bactérias Gram-Positivas \\
- Gram-Positive Bacterial Infections"
\end{tabular}

continued... ...continuation

\begin{tabular}{|c|l|}
\hline I & $\begin{array}{l}\text { "Metronidazole" OR "Nitroimidazóis } \\
\text { Nitroimidazoles" OR "Anti-Infecciosos - Anti-Infection" } \\
\text { OR "Antibacterianos - Antibacterial" }\end{array}$ \\
\hline C & No comparison. \\
\hline O & $\begin{array}{l}\text { "Neutralizadores de Odores - Odor neutralization" } \\
\text { OR "Odores - Odors" OR "Desodorização - } \\
\text { Deodorization" }\end{array}$ \\
\hline
\end{tabular}

For the selection and inclusion of articles in the systematic review (SR), the following criteria were defined: studies in which (human) wounds were topically treated with metronidazole; published in full; published in national and international journals indexed in the established databases, and without language barrier.

Data collection was carried out in the 1 st semester of 2015 by electronic search (internet) without data restriction, performed on each of the five selected databases. All studies retrieved consistent with the research strategy were evaluated according to the title and abstract by two independent researchers. Even in cases where data were not sufficient, studies were included in pre-selection, thereby avoiding erroneous deletions. After the studies were obtained in full, they had their references checked, in order to recover possible studies not yet verified. Data were collected during full article readings, through a specific instrument containing: title, journal, year, main author, type of study, solution used.

Data were analyzed in three stages:

Phase 1 - Characterization of the selection process of studies: analysis of data concerning the total number of studies recovered by databases. After searching the databases, two different researchers individually analyzed the retrieved articles (by title and abstract) and identified articles relevant to the proposed theme - metronidazole in wounds. Studies to be read in full and those which would be included in the SR were selected by consensus.

Phase 2 - Characterization of included studies: analysis of data related to included studies by two researchers, such as title, journal, year, main author, study type, application method, concentration of metronidazole and outcome.

Phase 3 - Quality assessment and evidence of the included studies: studies had their quality (internal validity) assessed according to STROBE - Strengthening the Reporting of Observational studies in Epidemiology for observational studies ${ }^{(5)}$ and CONSORT - Consolidated Standards of Reporting Trials for clinical trials ${ }^{(6)}$ (case reports do not have internal quality evaluation).

For STROBE evaluation, each of the 22 criteria received a score from 0 to 1 ( 0 - described and 1 - not described). For evaluation according to CONSORT, also consisting of 22 items, scores were performed considering 0 - not described, 1 - partially described and appropriate and 2 - appropriate (in cases where not applicable, such as in uncontrolled clinical studies, items were not added). The total score was converted into percentages for better 
article evaluation. Items that reached a percentage higher than $70 \%$ were considered of good quality.

\section{RESULTS}

Research showed that there were no systematic reviews on the use of metronidazole in wound odor control. 26 studies were pre-selected, one study in animals and 6 studies per- formed by other means of administration of metronidazole (three orally, one intravenously and two studies did not describe the method of administration) and four review studies were excluded (Figure 1). Among the three letters to the editor identified, one describes a randomized clinical trial, but there was not enough data for study evaluation, so it was then deleted. 14 articles were included in the study (Chart 1).

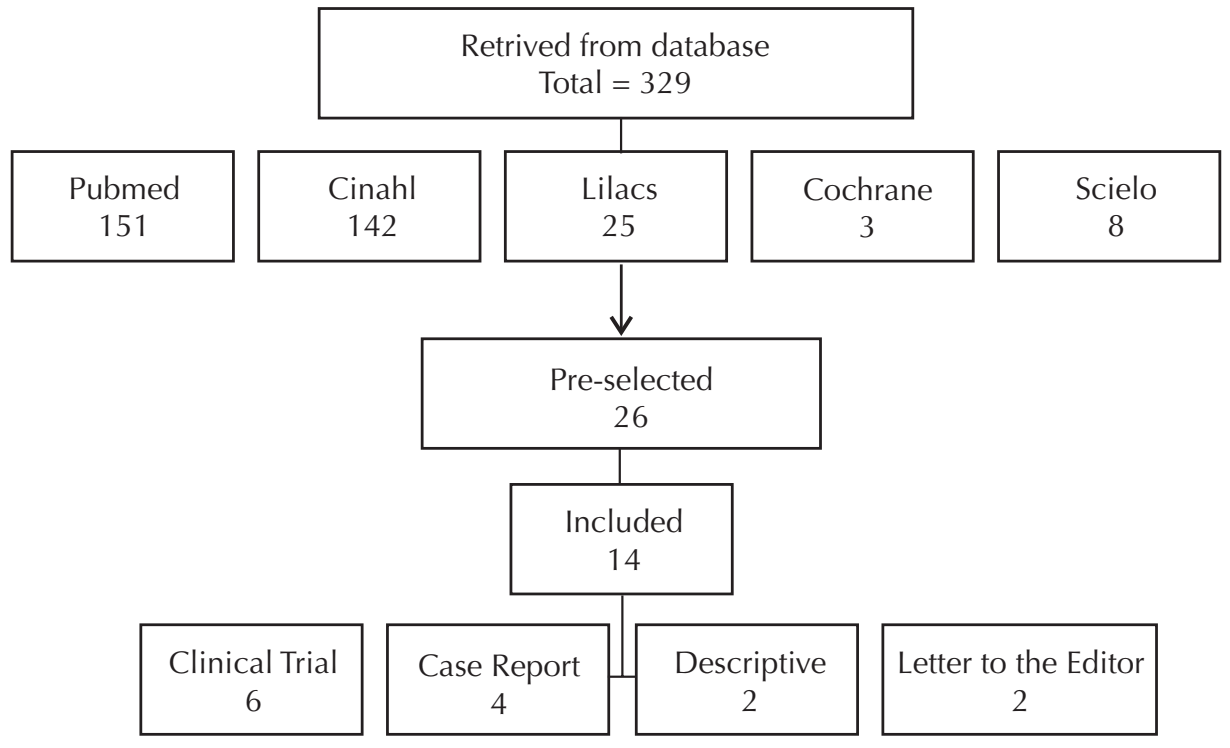

Figure 1 - Description of the strategy carried out for the search and inclusion of articles - São Paulo, SP, Brazil, 2015.

Chart 1 - Description of the 14 studies identified on the use of metronidazole in wounds for odor control - São Paulo, SP, Brazil, 2015.

\begin{tabular}{|c|c|c|c|c|c|}
\hline Author, year & Sample & Intervention & Application & Wound type & Outcome for odor control \\
\hline \multicolumn{6}{|c|}{ Letter to the Editor } \\
\hline 1978(7) & $\begin{array}{l}\text { Not reported. } \\
\text { Case report. }\end{array}$ & $\begin{array}{l}\text { Metronidazole } 1 \% \\
\text { solution, autoclaved } \\
\text { at } 121^{\circ} \mathrm{C} \text { for } 20 \\
\text { minutes. }\end{array}$ & Dampened gauze. & $\begin{array}{l}\text { Pressure ulcers, } \\
\text { diabetic ulcers, } \\
\text { venous ulcers } \\
\text { and abscesses. }\end{array}$ & $\begin{array}{l}\text { Odor reduction in a few hours. } \\
\text { Odorless in } 24 \text { hours, wounds clean } \\
\text { and free of anaerobic bacteria and } \\
\text { cellulite. } \\
\text { - No statistical result. }\end{array}$ \\
\hline Ashford, 1984(8) & $\begin{array}{l}12 \text { patients. } \\
\text { Randomized, } \\
\text { double-blind } \\
\text { case study. }\end{array}$ & $\begin{array}{l}\text { Comparison } \\
\text { of two groups: } \\
\text { metronidazole } \\
\text { 200mg } 3 \text { times a day } \\
\text { versus placebo. }\end{array}$ & $\begin{array}{l}\text { Does not describe } \\
\text { administration and } \\
\text { application. }\end{array}$ & $\begin{array}{l}\text { Malignant } \\
\text { neoplastic } \\
\text { wound. }\end{array}$ & $\begin{array}{l}\text { Experimental group had odor } \\
\text { reduction }(p<0.01) \text {, and reduction of } \\
\text { microbial load }(p<0.005) \text {. } \\
\text { CONSORT: } 42 \%\end{array}$ \\
\hline \multicolumn{6}{|c|}{ Case report } \\
\hline Ashford, 1980(9) & 1 patient & $\begin{array}{l}\text { Metronidazole } 200 \\
\text { mg } 3 \text { times a day. }\end{array}$ & $\begin{array}{l}\text { Does not describe } \\
\text { the form of } \\
\text { administration or } \\
\text { application. }\end{array}$ & $\begin{array}{c}\text { Malignant } \\
\text { neoplastic } \\
\text { wound. }\end{array}$ & Odor reduction in 1 week. \\
\hline Gomolin, 1983(10) & 4 patients & $\begin{array}{l}\text { Metronidazole } 1 \% \\
\text { solution. }\end{array}$ & $\begin{array}{l}\text { Moistened gauze, } \\
\text { changed every } 8 \mathrm{~h} \text {. }\end{array}$ & $\begin{array}{l}\text { Pressure ulcers in } \\
\text { stages II to IV. }\end{array}$ & $\begin{array}{c}\text { Odor reduction from } 48 \text { hours to } 1 \\
\text { week. }\end{array}$ \\
\hline Pierleoni, 1984(11) & 2 patients & $\begin{array}{l}\text { Metronidazole } 1 \% \\
\text { solution. }\end{array}$ & $\begin{array}{l}\text { Moistened gauze, } \\
\text { changed every } 8 \mathrm{~h} .\end{array}$ & $\begin{array}{l}\text { Pressure ulcers in } \\
\text { stages III and IV. }\end{array}$ & High reduction in odor control. \\
\hline Burnakis, 1989(12) & 1 patient & $\begin{array}{l}\text { Metronidazole } 1 \% \\
\text { solution, autoclaved } \\
\text { at } 121^{\circ} \mathrm{C} \text { for } 20 \\
\text { minutes. }\end{array}$ & $\begin{array}{l}10 \mathrm{ml} \text { of solution } \\
\text { was applied to } \\
\text { gauze at each } \\
\text { shift. After the } \\
\text { gauze dried, it } \\
\text { was removed, } \\
\text { "warm light" was } \\
\text { applied for } 20 \text { to } 30 \\
\text { minutes. }\end{array}$ & $\begin{array}{l}\text { Pressure ulcer } \\
\text { (stage was not } \\
\text { described). }\end{array}$ & Odor reduction in 24 to 48 hours. \\
\hline
\end{tabular}


...continuation

\begin{tabular}{|c|c|c|c|c|c|}
\hline Author, year & Sample & Intervention & Application & Wound type & Outcome for odor control \\
\hline \multicolumn{6}{|c|}{ Descriptive } \\
\hline $\begin{array}{l}\text { Witkowski1, } \\
\text { 1991(13) }\end{array}$ & 10 patients & $\begin{array}{l}\text { Metronidazole gel } \\
\text { (without description } \\
\text { of concentration). }\end{array}$ & $\begin{array}{l}\text { Soak with } \\
\text { saline solution, } \\
\text { application of a } \\
\text { thin layer of gel } \\
\text { covered with } \\
\text { gauze. Changed } \\
\text { every } 12 \text { hours. }\end{array}$ & $\begin{array}{l}\text { Sacral pressure } \\
\text { ulcer stages III } \\
\text { to IV. }\end{array}$ & $\begin{array}{c}\text { Odor elimination of all wounds in } \\
36 \text { hours. } \\
\text { - No statistical results. } \\
\text { STROBE: } 46 \%\end{array}$ \\
\hline $\begin{array}{l}\text { McMullen, } \\
1992(14)\end{array}$ & 11 patients & $\begin{array}{l}\text { Metronidazole } \\
0.75 \% \text { gel in } \\
\text { wounds and } 1 \% \\
\text { solution for fistulas }\end{array}$ & $\begin{array}{l}\text { Applied } 1 \text { or } 2 \\
\text { times a day. }\end{array}$ & $\begin{array}{l}\text { Malignant } \\
\text { neoplastic } \\
\text { wound, } \\
\text { Radiodermatitis, } \\
\text { fistula and } \\
\text { pressure ulcer. }\end{array}$ & $\begin{array}{c}\text { After } 24 \text { hours the odor was noticed } \\
\text { only at bandage opening/removal; in } \\
5 \text { days odor was eliminated. } \\
\text { - No statistical results. } \\
\text { STROBE: } 61 \%\end{array}$ \\
\hline \multicolumn{6}{|c|}{ Clinical Trial } \\
\hline $\begin{array}{l}\text { Newman, } \\
\text { 1989(15) }\end{array}$ & 68 patients & $\begin{array}{l}\text { Metronidazole } 0.8 \% \\
\text { gel }\end{array}$ & $\begin{array}{l}\text { Application of } \\
\text { metronidazole } \\
\text { gel covered with } \\
\text { gauze. Changed } \\
\text { once a day. }\end{array}$ & $\begin{array}{l}\text { Not described, } \\
\text { only mentions } \\
\text { that wounds are } \\
\text { fetid. }\end{array}$ & $\begin{array}{l}\text { Odor reduction in } 96 \% \text { of the } \\
\text { subjects, where } 50 \% \text { were total } \\
\text { control and } 46 \% \text { were partial } \\
\text { control. } \\
\text { - No statistical results. } \\
\text { CONSORT: } 62 \%\end{array}$ \\
\hline Bower, 1992(16) & 9 patients & $\begin{array}{l}\text { Comparison } \\
\text { of two groups: } \\
\text { metronidazole } 0.8 \% \\
\text { gel versus placebo. }\end{array}$ & $\begin{array}{l}\text { Placebo or } \\
\text { metronidazole } \\
\text { gel applied once } \\
\text { a day for } 5 \text { days, } \\
\text { followed by } 6 \text { days } \\
\text { of metronizadole. }\end{array}$ & $\begin{array}{l}\text { Malignant } \\
\text { neoplastic } \\
\text { wound. }\end{array}$ & $\begin{array}{c}\text { Odor reduction in } 5 \text { days for } \\
\text { experimental group }(p<0.001) \text {. } \\
\text { CONSORT: } 71 \%\end{array}$ \\
\hline Finlay, $1996^{(17)}$ & 39 patients & $\begin{array}{l}\text { Metronidazole } \\
0.75 \% \text { gel. }\end{array}$ & $\begin{array}{l}\text { Application } \\
\text { of gauze with } \\
\text { metronidazole gel. }\end{array}$ & $\begin{array}{l}\text { Neoplastic } \\
\text { wounds and leg } \\
\text { ulcers. }\end{array}$ & $\begin{array}{l}\text { Odor reduction with metronidazole } \\
\qquad(p<0.002) . \\
\text { CONSORT: } 84 \%\end{array}$ \\
\hline Kuge, $1996^{(18)}$ & 5 patients & $\begin{array}{l}\text { Comparison } \\
\text { of two groups: } \\
\text { metronidazole } 0.8 \% \\
\text { gel versus placebo. }\end{array}$ & $\begin{array}{l}\text { Applied } 1 \text { or } 2 \\
\text { times a day. }\end{array}$ & $\begin{array}{l}\text { Wounds caused } \\
\text { by breast cancer. }\end{array}$ & $\begin{array}{c}\text { Odor reduction or elimination from } \\
2 \text { to } 5 \text { days in the experimental } \\
\text { group. } \\
\text { - No statistical results. } \\
\text { CONSORT: } 65 \%\end{array}$ \\
\hline Bale, $2004^{(2)}$ & 41 patients & $\begin{array}{l}\text { Comparison } \\
\text { of two groups: } \\
\text { metronidazole } 0.8 \% \\
\text { gel versus placebo. }\end{array}$ & $\begin{array}{l}1 \text { application once } \\
\text { a day. }\end{array}$ & $\begin{array}{l}\text { Arterial, venous, } \\
\text { dehiscence and } \\
\text { pressure ulcer. }\end{array}$ & $\begin{array}{c}100 \% \text { reduction for group with } \\
\text { metronidazole versus } 76 \% \text { placebo } \\
(p<0.05) . \\
\text { CONSORT: } 68 \%\end{array}$ \\
\hline Kalinski, $2005^{(19)}$ & 16 patients & $\begin{array}{l}\text { Metronidazole } \\
0.75 \% \text { gel. }\end{array}$ & $\begin{array}{l}\text { Applied } 1 \text { or } 2 \\
\text { times a day. }\end{array}$ & $\begin{array}{l}\text { Neoplastic } \\
\text { wounds. }\end{array}$ & $\begin{array}{l}100 \% \text { odor reduction. } \\
\text { CONSORT: } 73 \%\end{array}$ \\
\hline
\end{tabular}

\section{DISCUSSION}

In $1978^{(7)}$, one study reported (in the form of a letter to the editor) the putrid odor that some pressure ulcers exuded and other cases in which patients progressed to sepsis caused by anaerobic bacteria. The authors describe that from previous publications on the successful treatment of patients with sepsis caused by anaerobic bacteria through systemic metronidazole, they began to suggest its topical use on infected wounds. In the same report, the authors mention that there was a lack of topical formulations at that time, therefore the hospital pharmacy manipulated a metronidazole $1 \%$ solution, and applied it to pressure ulcers, diabetic ulcers, leg ulcers and venous ulcers with odor, through moistened gauze. As the outcome, there was odor reduction from the wounds within a few hours, in addition to there being negative cultures on the surface of the wounds after 24 hours.

In 1980, other authors ${ }^{(9)}$ proposed the use of metronidazole for odor control in neoplastic wounds for the first time, to publish a case report in which the wound had offensive and putrid odor - characteristic of infection by anaerobes. They proposed a local treatment with $200 \mathrm{mg}$ of metronidazole three times a day, with no description of the form of administration (oral, intravenous or topical). They found odor reduction in a week, which they only noticed when they removed the dressing and it was less offensive than before. According to the authors, the patient returned to work as a teacher, noting that this would be unlikely in the previous condition, improving their quality of life and without any toxicity.

Currently, topical metronidazole is recommended for wounds to control odor through its action on anaerobic bacteria responsible for producing volatile acids, which cause the odor, without the side effects of oral use ${ }^{(19)}$. Topical application of metronidazole has little or no systemic absorption $^{(20)}$.

According to this review, topical wound therapy uses metronidazole solution in 0.75 and $0.8 \%$, in the form of a gel or liquid. However, some authors describe its application 
by macerating oral tablets with subsequent dilution; others only describe that it was manipulated without detailing how this was done, and others describe the use of Metrotop ${ }^{\circledR}$ (metronidazole $0.8 \%$ gel not available in Brazil). No instruments for the evaluation of odor have been identified, which compromises the interpretation of results when this is described as odor reduction.

Despite being identified in only two randomized clinical trials on topical metronidazole therapy for wounds, the results showed different outcomes (making it impossible to conduct meta-analysis). Clinical experience suggests that metronidazole is effective in odor control, especially in neoplastic (cancer) wounds ${ }^{(19)}$.

In Brazil, metronidazole is available in the form of vaginal cream $(8 \%-400 \mathrm{mg} / 5 \mathrm{~g}$ and $10 \%-500 \mathrm{mg} / 5 \mathrm{~g})$, oral suspension $(40 \mathrm{mg} / \mathrm{ml})$, oral tablets/pills $(250 \mathrm{mg}$ or $400 \mathrm{mg}$ ) and parenteral solution (0.5\%). Topical formulations have high concentration because the amount of cream/ointment applied is small, about 5 to $10 \mathrm{~g}$ in the treatment of vaginitis or acne rosacea.
Two Brazilian oncology hospitals report using pills diluted in saline solution at bedside in their protocols for odor control of neoplastic wounds; and silver and papain are used for odor control of other etiologies ${ }^{(21)}$.

Because there are no ready-made metronidazole $0.8 \%$ topical formulations, manipulation becomes necessary - for example metronidazole tablets associated to physiological saline solution (off-label use) $)^{(22-23)}$.

\section{CONCLUSION}

Based on the results of this systematic review, the metronidazole solution is recommended in clinical practice to control odor in infected wounds, and used more appropriately in malignant neoplastic wounds, but there are no randomized controlled trials of strong evidence to effectively support this. Other clinical studies of stronger evidence should be performed so we can use off-label metronidazole more assertively and clinically safe.

\section{RESUMO}

Objetivo: Verificar as evidências da aplicação tópica de metronidazol na eficácia terapêutica para controle de odor de feridas. Método: Revisão sistemática de literatura, segundo as recomendações da Cochrane Collaboration. Resultados: Identificaram-se 329 artigos nas bases de dados Cochrane, LILACS, ScIELO, Cinahl e PubMed, incluindo-se 14 deles na amostra final. Desses, dois estudos são do tipo ensaio clínico, randomizado e duplo-cego. Conclusão: Devido à ausência de estudos de forte evidência sobre a eficácia do metronidazol no controle de odor em feridas, ainda não se pode evidenciar a sua real eficácia para tal objetivo, apesar da prática clínica recomendar seus benefícios.

\section{DESCRITORES}

Ferimentos e Lesões; Desodorização; Metronidazol; Infecção dos Ferimentos; Revisão.

\section{RESUMEN}

Objetivo: Verifying the evidence of therapeutic efficacy in the topical application of metronidazole for controlling wound odor. Methods: A systematic literature review, according to the Cochrane Collaboration recommendations. Results: 329 articles were identified in the Cochrane, LILACS, SciELO, CINAHL and PubMed databases, with 14 of them being included in the final sample. Two of the studies were double-blind randomized clinical trial studies. Conclusion: The actual effectiveness of metronidazole in controlling wound odor cannot yet be evidenced due to the absence of strong evidence from studies on the subject, despite clinical practice recommending its benefits.

\section{DESCRIPTORES}

Wounds and Injuries; Deodorization; Metronidazole; Wound Infection; Review.

\section{REFERENCES}

1. Sarabahi S. Recent advances in topical wound care. Indian J Plast Surg. 2012;45(2):379-87.

2. Bale S, Tebbie N, Prince P. A topical metronidazole gel used to treat malodorous wounds. Br J Nurs. 2004;13(11):S4-11.

3. Morris C. Wound odour: principles of management and the use of Clinisorb. Br J Nurs. 2008; 17(6):S38-42.

4. Higgins JPT, Green S, editors. Cochrane handbook for systematic reviews of interventions version 5.1.0 [updated March 2011]. London: The Cochrane Collaboration; 2011.

5. Malta M, Cardoso LO, Bastos FI, Magnanini MMF, Silva CMFP. STROBE initiative: guidelines on reporting observational studies. Rev Saúde Pública [Internet]. 2010 [cited 2014 Oct 12];44(3):559-65. Available from: http://www.scielo.br/pdf/rsp/v44n3/en_21.pdf

6. Altman DG, Schultz KF, Moher D, Egger M, Davidoff F, Elbourne D, et al. The revised CONSORT statement for reporting randomized trials: explanation and elaboration. Ann Intern Med. 2001;134(8):663-94.

7. Jones PH, Willis AT, Ferguson IR. Treatment of anaerobically infected pressure sores with topical metronidazole. Lancet. 1978;1(8057):2134.

8. Ashford R, Plant G, Maher J, Teare L. Double-blind trial of metronidazole in malodorous ulcerating tumours. Lancet. 1984;1(8388):1232-3.

9. Ashford RFU, Plant GT, Maher J, Pickering D, Coe MA, Drury A, et al. Metronidazole in smelly tumors. Lancet. 1980;1(8173):874-5. 
10. Gomolin IH, Brandt JL. Topical metronidazole therapy for pressure sores of geriatric patients. J Am Geriatr Soc. 1983;31(11):710-2.

11. Pierleoni EE. Topical metronidazole therapy for infected decubitus ulcers. J Am Geriatr Soc. 1984;32(10):775.

12. Burnakis TG. Topical metronidazole for decubitus ulcers. Hosp Pharm. 1989;24(11):960-1.

13. Witkowski JA, Parish LC. Topical metronidazole gel: the bacteriology of decubitus ulcers. Int J Dermatol. 1991;30(9):660-1.

14. McMullen D. Topical metronidazole. Part II. Ostomy Wound Manage. 1992;38(3):42-6, 48.

15. Newman V, Allwood M, Oakes RA. The use of metronidazole gel to control the smell of malodours lesions. Palliat Med. 1989;3(4):303-5.

16. Bower M, Stein R, Evans TR, Hedley A, Coombes RC. A doble-blind study of the efficacy of metronidazole gel in the treatment of malodorous fungating tumours. Eur J Cancer. 1992;28A(4-5):888-9.

17. Finlay IG, Bowszyc J, Ramlau C, Gwiezdzinski Z. The effect of topical 0,75\% metronidazole gel on malodours cutaneous ulcers. J Pain Symptom Manage. 1996;11(3):158-62.

18. Kuge S, Tokuda Y, Ohta M, Okumura A, Kubota M, Ninomiya S, et al. Use of metronidazole gel to control malodor in advanced recurrent breast cancer. Jpn J Clin Oncol. 1996;26(4): 207-10.

19. Kalinski C, Schnepf M, Laboy D, Hernandez L, Nusbaum J, McGrinder B, et al. Effectiveness of topical formulation containing metronidazole for wound odor and exudate control. Wounds. 2005;17(4):84-9.

20. Finegold SM. Anaerobic infections in humans: an overview. Anaerobe. 1995;1(1):3-9.

21. Matsubara MGS, Villela DL, Hashimoto SY, Silva Reis HC, Saconato RA, Denardi UA, et al. Feridas e estomas em oncologia: uma abordagem interdisciplinar. São Paulo: Lemar; 2011.

22. Brasil. Ministério da Saúde; Secretaria de Ciências, Tecnologias e Insumos estratégicos, Comissão Nacional de Incorporação de Tecnologias no SUS. Uso off label: erro ou necessidade? Rev Saúde Pública. 2012;46(2):398-9.

23. Brasil. Ministério da Saúde; Agência Nacional de Vigilância Sanitária (ANVISA). Como a ANVISA vê o uso off label de medicamentos [Internet]. Brasília; 2005 [citado 2014 out. 12]. Disponível em: http//www.anvisa.gov.br/medicamentos/registro/registro_offlabel.htm 